\title{
Significance of Ayurveda in Regulating Periods in Patients with PCOS/PCOD
}

\author{
Rajalakshmi Ramesh* \\ Senior Practitioner-Ayurveda and Yoga Therapist Ayurmedics Clinic, United Kingdom \\ *Corresponding author: Rajalakshmi Ramesh, Senior Practitioner-Ayurveda and Yoga \\ Clinical Note \\ Volume 2 Issue 5 \\ Received Date: July 16, 2018 \\ Published Date: July 24, 2018
}

Therapist Ayurmedics Clinic, 505, London Road, Thronton Heath Surrey, Cr7 6ar, United Kingdom, Tel: 078-5043-9999;

Email: ayurmedics@gmail.com

\section{Clinical Note}

One of the major challenges faced in women's health today is PCOS, PCOD and unexplained infertility. PCOS is the most common endocrine disorder among women between the ages of 18 and 44. It affects approximately $2 \%$ to $20 \%$ of this age group depending on how it is defined. It is one of the leading causes of poor fertility. PCOS mostly produces oligomenorrhea (few menstrual periods) or amenorrhea (no menstrual periods), and this is where Ayurveda plays a significant role to regulate periods among such category of women.

Ayurveda gives a detailed description under the title of menstrual disorders. One of the earliest descriptions of menstrual disorders was made by author Sushrutha under the heading of Artavavyapad (menstrual disorders). There are eight type of menstrual disorders enumerated by Sushrutha based on the dosa predominance i.e, vataja, pitaja, kaphaja, vata with pita, pita with Vata, Vata with kapha and tridosaja i.e, combination of all the 3 dosas. According to Ayurveda, arthava (menstrual blood) is formed from rasa (primary waters of the body) and blood (rakta).

Therefore the principle treatment will be to increase rasa and rakta in menstrual disorders. General causes for menstrual disorders include specific factors responsible to aggravate the particular dosas, general weakness in childhood, infection/inflammation of reproductive organs, diseases of endometrium, oestrogen deficiency and other non-observance of regulations related to reproductive system.
The general age group of the patients will be between 17 to 37. The main criteria for these patients to resort to Ayurveda are the prescription of contraceptive pills in modern medicine to regulate their periods. Most often, they are worried about the long term side effects of the pill although it helps regulate their periods. This is where Ayurveda plays a pre dominant role in today's modern world and is boon to these women since it not only regulates their periods, but also helps them in conception thereafter.

Primary principle of treatment is cleansing the reproductive system through oleation, sudation, emetics and purgatives followed by Uttara basti (vaginal instillation) at the end. Chakrapani in his texts clearly states that loss of aarthava (menstruation) is due to aggravation of vayu. Therefore our basis of treatment is to treat the factors responsible for derailed / aggravated vata. All our patients go through the detoxification procedures followed by tailor made diet plan depending on the dosa which is involved in each case. Once the detoxification is completed, they are prescribed a course of herbs in different combinations which generally contain Shatavari, Triphala, Aloevera, Shatapushpa, as the saying goes (shatapushpa shataveeryou syathaam thathamrtham yatha) meaning the above mentioned drugs are like nectar for women who have menstrual disorders [1].

We have recorded the response to the treatment and therapeutic effects were evaluated by symptomatic relief and through Scans and LH, FSH hormone levels. The 


\section{Journal of Natural \& Ayurvedic Medicine}

results revealed that, oligomenorrhoea/ amenorhoea and sub fertility due to PCOS can be cured successfully by using this Ayurveda treatment regimen. 60 percent of the patients almost reinstate their cycles within 3 months. This safe method using natural herbs without impending side effects is a big relief to women with PCOD.

Stress and sedentary life style adds up to the severity of PCOS/PCOD leading to infertility particularly in this part of the world. We therefore integrate Yoga within our treatment plan and advocate medication to alleviate stress and therapeutic yoga classes to work on obesity which is common symptom seen among these patients.
Essentially PCOS should be taken care in the beginning itself. But most of the time it is diagnosed only in later period or else it is neglected that it is a minor health complaint or simple menstrual irregularity. Early detection and immediate attention will help to curb the disease as well as to avoid the complications like infertility.

\section{Reference}

1. Tiwari PV (1999) Ayurvediya Prasuti Tantra Evam Stree Roga (Part1\&2), Chaukhamba Publisher pp: $48+754(\mathrm{I}), 32+636(\mathrm{II})$. 